\title{
Photography as a Space for Constructing Subjectivities: Luxembourg's Steel Dynasties and the Modern Workforce as Seen through the Glass Plate Negatives from the Institut Emile Metz
}

\author{
Françoise Poos
}

The Institut Emile Metz was founded in 1913 in Dommeldange, a suburb of the city of Luxembourg, by Caroline Rosalie Laure Edmée Metz-Tesch, the wealthy widow of Emile Metz, one of Luxembourg's leading industrialists. ${ }^{1}$ The Luxembourg publisher and writer Jules Mersch described her as the epitome of the Belle Epoque: as a young woman, she would be richly powdered and elegantly dressed, a stylish umbrella perfectly matching her gown, when she rode to town in her open carriage. ${ }^{2}$ Her taste was exquisite and refined. As a welleducated member of the upper bourgeoisie, Edmée Metz-Tesch liked to shop at exclusive places: bills from her personal archive show her as a customer of Hellstern \& Sons, a famous store for bespoke fashion on Place Vendôme in Paris. ${ }^{3}$

1 Emile Metz (1835-1904) was the eldest son of the Luxembourg politician and industrialist Norbert Metz. He succeeded his father as the manager of Metz and Company and as administrator of the Société des Hauts Fourneaux de Dudelange. In 1886, he was appointed general manager of the Usines d'Esch. Importantly, he was also the first to acquire, in April 1879, an independent license for the exploitation of the process of dephosphorizing lower quality iron ore, which was invented and elaborated between 1874 and 1878 by Sidney Thomas and Percy Gilchrist, and thus made steel production in Luxembourg possible. Until then, the iron ore found in the country, because of its high concentration of phosphorus, only allowed the production of cast iron. The license that Emile Metz acquired represented therefore a pivotal moment in the history of Luxembourg steel making. See also Jos[eph] Wagner and Camille Aschman, "Fondateurs d'usines, maîtres de forges et grands maîtres de l'industrie sidérurgique luxembourgeoise," Revue Technique Luxembourgeoise 29, no. 6 (November-December 1937): 133-52.

2 See Jules Mersch, "Les Metz, la Dynastie du Fer," in Biographie nationale du pays de Luxembourg, vol. 6, fascicule 12 (Luxembourg City: Bourg Bourger, 1963), 383.

3 See Jean Lamesch, "Histoire de la Fondation Veuve Emile Metz-Tesch," in IEM-LTPEM: 100 Joer, 1914-2014, ed. Alphonse Bressanutti, Fernand Champagne, Laurent Kemp, Siggy Kirsch, Pierre Legille, and René Tissier (Luxembourg: LTPEM, 2015), 70. 
Her lavishly decorated hats came from a renowned milliner in Brussels. She also appreciated the inventions and comforts of modernity: She had a driver's license and had installed in her residence a phone as well as boilers that made possible more regular and continuous heating than the traditional fireplaces. ${ }^{4}$

Most striking, however, was her reading list. Among her bills, Luxembourg scholar Jean Lamesch discovered an order from a bookstore in Brussels featuring the Memoirs of Casanova and Mirabeau's Lettres à Julie (Letters to Julie), as well as a copy of Marc de Villiers' Histoire des clubs de femmes et des legions d'Amazones (1793) (History of women's clubs and Amazon legions), conveying progressive ideas on marriage, divorce, and female education. Edmée MetzTesch also read Madame de Gaffigny's epistolary novel Lettres d'une Péruvienne (1747) (Letters from a Peruvian woman), promoting the idea of the "noble savage," and the writings of Anatole France, the French Academician and winner of the 1921 Nobel Prize for Literature, who was active in the social and political issues of his time. ${ }^{5}$ Judging from the material objects that accompanied her life, Edmée Metz-Tesch thus appears as a modern, independent, and openminded woman, with a keen interest in the betterment of society. This commitment translated, tangibly, into the creation of the Institut Emile Metz.

The idea for a vocational school in honor of her husband's memory was originally suggested to her by Emile Bian, director of the Dommeldange steel plant from 1900 until 1911. The idea appealed to her from the start, but it seems that Edmée Metz-Tesch had grander visions on how to contribute to the growth of the industry than merely training a largely unqualified workforce. Metz-Tesch instead conceived of a technological institute, with state-of-the-art facilities, bright, well-lit classrooms, clean workshops, a gym, even an indoor pool, to which would later be added a psychophysiological laboratory where the students' skills and capacities were to be tested and developed. According to an official publication listing and describing ARBED's corporate welfare initiatives, her declared aims were, "To better the fate of the worker. To raise his physical and intellectual capacities. To awaken latent intelligencies."6 "Of high lineage and a strong individualistic streak," noted the same publication, "the daughter of Minister Victor Tesch was particularly well prepared to understand the part of contingency in happiness, and to conceive happiness as the emanation of one's personality."7 The development of individuality and the

4 Ibid.

5 Ibid., $72-73$.

6 ARBED, OEuvres sociales (Luxembourg: Victor Bück, 1922), 41. Unless otherwise noted, all translations are the author's.

7 Ibid. 
achievement of personal fulfilment thus were important concerns in the creation of the Institut Emile Metz.

Whether these aims have been truly met is a question that transcends the scope of this paper, and a detailed analysis of the corporate discourse surrounding the Institut Emile Metz and its impact on the workforce still needs to be written. In popular texts, however, the new training institute established by Edmée Metz-Tesch was generally seen as a ladder of upward social mobility, and its progressive teaching methods were discussed at international conferences on reform education. ${ }^{8}$ Moreover, the architectural design of the school seemed to be the visible manifestation of the generous vision of its benefactress: entirely made of cut stone, the building testified to stateliness and stability, while the sturdy columns adorning the front entrance conveyed an image of monumentality and continuity. ${ }^{9}$ The teaching facilities, the classrooms, the dressing and locker rooms, and the workshop spaces corresponded to progressive norms of hygiene and were designed to create a positive learning environment.

Not surprisingly, the Institut Emile Metz was presented as a showcase of the company's corporate welfare initiatives in the field of education..$^{10}$ As such, it was abundantly documented not only through texts but also through photographs, including carefully crafted views of the institute's interior and exterior spaces and adjacent workshops, class pictures, and images of the school's own Boy Scout troop, Les Loups Blancs, founded in 1914. These images and many more resurfaced in 2007, when a group of alumni discovered a collection of about 2,400 glass plates in the school's attic, where they had been abandoned and eventually forgotten. The plates had been made between 1913 and 1962, starting with images of the construction of the institute and ending with the

8 See Lise Linster, "Das Institut Emile Metz - eine Stufe zum sozialen Aufstieg," Koplescht, fréier an hott 10 (October 2013): 56-62; Frederik Herman, "Forging Harmony in the Social Organism: Industry and the Power of Psychometric Techniques," History of Education 43, no. 5 (2014): 592-614; Frederik Herman, Karin Priem, and Geert Thyssen, "Körper_ Maschinen? Die Verschmelzung von Mensch und Technik in Pädagogik, Industrie und Wissenschaft," Jahrbuch für Historische Bildungsforschung 20 (2014): 47-75.

9 Lamesch, "Histoire de La Fondation Veuve Emile Metz-Tesch," 71-72.

10 For the company's own early representations of the Institut Emile Metz, see, for instance, ARBED, CEuvres sociales; Institut Emile Metz: Programme publié à la clôture de l'année 19171918 (Luxembourg: Imprimerie Universelle Linden et Hansen, 1918); Jean-Pierre Arend, "L'Evolution de l'Institut Emile Metz et l'atelier d'apprentissage," in Institut Emile Metz: Programme publié à la clôture de l'année scolaire 1920-1921 (Luxembourg: Imprimerie Th. Schroell, 1921), 55-64. 
documentation of a flood in Dommeldange. The boxes had been meticulously annotated, but their order had not been preserved over time, and they arrived at Luxembourg's Centre national de l'audiovisuel (CNA) as a seemingly disparate ensemble, including motifs and subjects as diverse as school life and educational records, industrial products, construction sites, the steel plant, commemorations and gatherings, as well as portraits of directors, workers, and employees. By covering such a variety of subjects, the glass plates give insight into the lived history not only of the school but of the entire corporation, while also testifying to the role of photography in consolidating the corporate image of ARBED both in Luxembourg and abroad.

The glass plate holding can be approached from many different perspectives. However, in keeping with the thematic focus of this publication on "the body in education," this article explores how the glass plates found at the Institut Emile Metz visually formed the subjectivities of both the workers and captains of the steel industry, but also - using the example of Edmée Metz-Tesch-of the industry's leading women. These investigations led me to consider photography as a space for constructing visions of embodied subjectivities. Photographs are multi-layered, complex objects, deeply entangled with and embedded in the everyday lives of their makers and users. This article, therefore, needs to been seen in the wider context of investigations about how photographs, as image surfaces and material objects, shape the way we see and understand the world. In the specific context of this publication on the intersection of photography and industry, I propose to analyze how photography as a medium was instrumental in shaping and disseminating the public image of the steel industry in Luxembourg, and how photographs helped form the public perception and understanding of this corporate hierarchical universe.

The historical timeframe for my exploration is the advent of modernity in Luxembourg in the first half of the twentieth century, a time of rapid industrialization and profound societal change. The "worker" as a type or a trope had barely appeared on the national horizon, in a country that had been largely agrarian until the consolidation of the steel industry in 1911 with the creation of the conglomerate ARBED (Aciéries réunies de Burbach-Eich-Dudelange). The workforce necessary for the success of the undertaking had yet to be produced, hence the creation of schools such as the Institut Emile Metz. Moreover, these newly created subjects and subjectivities also needed to be governed and managed in novel ways by the founders, directors, and managers of the steel industry. Their wives, though often working in the background, were active in the creation of social welfare or cultural initiatives and thus also played an important role in the formation of the modern workforce. 
This article is built around two main theoretical concepts: the idea of photographs as material objects entangled in the lived history of their makers and users; and the notion of the subjective body, or the construction of subjectivities. For a contemporary definition of subjectivity, I draw on the work of American cultural historian Michael O'Mally who argues that subjectivity is the "sense of self" resulting from the subjection of the self to a set of external influences and power relations. "Subjectivity," he writes, "implies not just the individual's sense of self, but the ways that sense of self is acted on and even made up by outside forces."11 The outside forces that I want to consider in this context are the development of the steel industry in Luxembourg and photography as a means of making visible the various new subjectivities in the modern age.

The French philosopher Michel Foucault has been influential in shaping my understanding of how people can be governed through "a certain policy of the body, a certain way of rendering the group of men docile and useful."12 As a mass medium of visual representation, photography, I want to argue, was part of this modern way of managing subjectivities in the age of mass production. Indeed, in the words of art critic Jonathan Crary,

Within this new field of serially produced objects, the most significant, in terms of their social and cultural impact, were photography and a host of related techniques for the industrialization of image making. The photograph becomes a central element not only in a new commodity economy but in the reshaping of an entire territory on which signs and images ... circulate and proliferate. ... Photography and money become homologous forms of social power in the nineteenth century. They are equally totalizing systems for binding and unifying all subjects within a single global network of valuation and desire. ${ }^{13}$

The most obvious manifestation of the power of photographs resides in their visual surfaces. In that sense, the glass plate collection from the Institut Emile

11 Michael O'Mally, “Subjectivity'—What Is It?," The Aporetic, http://theaporetic.com/? page_id $=2184$.

12 Michel Foucault, Discipline and Punish: The Birth of the Prison, trans. Alan Sheridan (London: Allen Lane, 1977), 305. In his book, Foucault specifically discussed the disciplinary effect of Jeremy Bentham's Panopticon, which made it possible to observe the prisoners' every movement, continually exposing them to an outside observer.

13 Jonathan Crary, Techniques of the Observer: On Vision and Modernity in the Nineteenth Century (Cambridge, MA: MIT Press, 2005), 13. 
Metz is an enticing selection with compelling motifs and attractive compositions. However, a semiotic analysis focusing on image content alone does not yield much information about the meaning of these photographic objects. I therefore propose to look at the glass plates "beyond the visual" and to consider them as material objects with active agency in this "global network of valuation and desire." ${ }^{4}$ The photographs under scrutiny thus need to be seen as "objects to think with," to borrow a phrase coined by visual anthropologist Elizabeth Edwards. ${ }^{15}$ As working tools and "bundled objects," 16 they are deeply embedded and entangled in a complex and multi-layered meshwork of social relations and performances. ${ }^{17}$ As such, they give insight into the lived history of the steel industry in Luxembourg, and the wishes and projections of its steel barons as the country entered modernity.

\section{The Glass Plate Negatives from the Institut Emile Metz}

In Luxembourg, as elsewhere, industrialization was synonymous with change: lifestyles changed, and so, importantly, did work rhythms, working hours, and work ethics. With so many profound transformations affecting the whole country, it was important for the corporation to communicate about itself, both internally and externally. The glass plates found at the Institut Emile Metz can therefore be seen as part of a larger photographic archive of ARBED constructed within the discursive space of corporate communications. Indeed, the company's headquarters and various plants regularly documented their activities through photographs. These images were made to propagate a positive image of the corporation, both to its own workers and employees and to the

14 Elizabeth Edwards, "Thinking Photography Beyond the Visual?," in Photography: Theoretical Snapshots, ed. J. J. Long, Andrea Noble, and Edward Welch (London: Routledge, 2006), 31-48; Elizabeth Edwards, "Photography and the Material Performance of the Past," History and Theory 48, no. 4 (2009): 130-50; Gillian Rose, Visual Methodologies: An Introduction to the Interpretation of Visual Materials, 2nd ed. (London: Sage, 2007).

15 Edwards, "Photography and the Material Performance of the Past," 131.

16 Elizabeth Edwards, "Photographs and History: Emotion and Materiality," in Museum Materialities: Objects, Engagements, Interpretations, ed. Sandra H. Dudley (London: Routledge, 2010), Kindle edition.

17 Françoise Poos, "The Making of a National Audio-Visual Archive: The CNA and the Hidden Images Exhibition" (PhD diss., De Montfort University, 2016). For the idea of objects as part of organic ecologies or wider meshworks of bindings and gatherings of lines, see Tim Ingold, Lines: A Brief History (London: Routledge, 2007); Tim Ingold, "Bindings against Boundaries: Entanglements of Life in an Open World," Environment and Planning A 40, no. 8 (2008): 1796-1810. 
outside world. There is thus an ideological component inherent in this communication, as cultural historian David Nye has stated more generally:

The corporation's creation and control of such materials is a metaphor for its cultural hegemony. ... Corporations edit archives, control access to papers, underwrite favorable works, destroy evidence (more often through neglect than by design), and lay down a barrage of favorable publicity that tells customers and stockholders how they ought to be understood. ${ }^{18}$

The first decades of the twentieth century clearly saw the emergence of industrial photographic communication all over the western world, and the collection discovered at the Institut Emile Metz is a self-contained and relevant example of this new practice. Similar archives can be found in other countries and for other industries. Krupp in Germany, for instance, has a company archive of about two million photographs. ${ }^{19}$ In the United States, the Ford Motor Company, General Electric, and the National Cash Register have equally impressive photographic holdings. ${ }^{20}$ If we agree that these photographs can also be understood as ideological tools, this implies that they were subtly articulated constructs, made for a specific purpose. In the case of the glass plates from the Institut Emile Metz, the question then is how to understand them as ideological instruments. And how does this relate to the portraits of workers and leading industrialists and the photographic representations of the influential women of Luxembourg's dynasties of steel? To investigate this issue, I want to focus on how the subjectivities of workers as well as of male and female leaders were constructed through these photographs.

The Genealogy of Steel in Luxembourg: Photographic Representations of Male and Female Leaders

In her seminal analysis of "Photography and Society," Gisèle Freund traced the history of the medium in France, showing how it was gradually adopted

18 David E. Nye, Image Worlds: Corporate Identities at General Electric, 1890-1930 (Cambridge, MA: Mit Press, 1985), 3.

19 See, for instance, Klaus Tenfelde, ed., Bilder von Krupp: Fotografie und Geschichte im Industriezeitalter (Munich: C. H. Beck, 1994); Krupp: Fotografien aus zweiJahrhunderten (Berlin: Deutscher Kunstverlag, 2011); Heinrich Theodor Grütter, ed., 20o Jahre Krupp: Ein Mythos wird besichtigt. Katalog zur Ausstellung im Ruhr Museum vom 31. März bis 4. November 2012 (Essen: Klartext, 2012).

20 Nye, Image Worlds; Elspeth H. Brown, The Corporate Eye: Photography and the Rationalization of American Commercial Culture, 1884-1929 (Baltimore, MD: Johns Hopkins University Press, 2008). 
throughout all societal classes. Importantly, she emphasized that it was the socially dominant classes-industrialists, bankers, statesmen, men of letters or science, and intellectuals - who first took to photography in the nineteenth century. ${ }^{21}$ In other words, Freund stresses the early and crucial link between photography and power. While intellectual and scientific curiosity and openness to a novel technology certainly led to an interest in photography, I would argue that the social elites not only responded to the excitement of the invention, but also to photography's potential to visually represent and promote ideas. Here, the photographs' portability as well as their reproducibility were particularly important.

Indeed, photographs are what Bruno Latour called "immutable mobiles"objects that are "mobile but also immutable, presentable, readable and combinable." 22 As such, they were able to infiltrate every stratum of society. This mobility was further enhanced through refinements in the half-tone process in the late nineteenth century, which allowed photographic images to be included in printed texts, books, newspapers, and magazines. On this new material support they could then travel, be seen, and discussed by a larger public. In Luxembourg, images of ARBED could thus enter public spaces and private homes while spreading and consolidating, both at home and abroad, the image of a steel empire in the making. ${ }^{23}$

To be recognizable, the corporation needed to be visible. Of crucial importance, therefore, was the representation of its key personalities, its founding fathers and directors, such as Emile Metz or Emile Mayrisch, who had shaped not only the company but, through their economic decisions and political influence, the entire country. Their authority and prominence had to be publicly stated and acknowledged, and photographs proved to be valuable tools in this endeavor-as I will show by using examples from the glass plate collection at the Institut Emile Metz and looking at their use in the print media. The wives and daughters of the leading industrialists played an important part, too. I will use two images of Edmée Metz-Tesch to show how women have been represented visually and how their subjectivities have been constructed within the universe of the steel corporation.

In 1937, Joseph Wagner, an engineer and department manager at ARBED Dommeldange, and Camille Aschman, a chemist at the same plant as well as a chemistry teacher at the Institut Emile Metz, published an article titled "Fondateurs d'usines, maîtres de forges et grands maîtres de l'industrie sidérurgique

21 Gisèle Freund, Photographie et société (Paris: Editions de Seuil, 1974), 21-33.

22 Bruno Latour, Science in Action: How to Follow Scientists and Engineers through Society (Milton Keynes: Open University Press, 1987), 26, emphasis in original.

23 For a discussion of how photographs were instrumentalized for the ideology of ARBED, see also Poos, "The Making of a National Audio-Visual Archive," 81-88. 
luxembourgeoise" (Mill Founders, Masters of Forges, and Grand Masters of the Luxembourg Steel Industry) in the Revue Technique Luxembourgeoise, a specialized journal aimed at engineers and industrialists. ${ }^{24}$ The paper presented what the authors called a "chart" of the most important figures in the history of Luxembourg's steel industry, starting in 1564 with William the Silent, Count of Nassau and Vianden, who had built the first iron ore melting furnace in the north of Luxembourg, and ending with Norbert Metz, who began his career as the head of the plants in Dudelange (1920) and Esch (1923) before becoming director at ARBED headquarters in Luxembourg in 1926. It was an anniversary issue of the Revue Technique, which explains the long and detailed historical overview. The declared aim of the authors was "to assemble a compilation of data and facts, established with a concern for authenticity for the use of those who want to research [the country's] industrial past, which still presents too many lacunae."25 The text itself was constructed as a succession of biographical entries of variable length. Taken together, the biographical notices are a genealogy of steel making in Luxembourg, showing the linkages and connections between families and interests.

Portraits, engravings, photogravures, or photographs complement the entries and reinforce the notion of a dynasty of steel barons, united in what resembles an ancestral portrait gallery. The visual editing underlines this sense of unity. All the portraits are headshots, framed at bust level, showing their subjects in a pose reflecting self-confidence and importance (see fig. 2.1). In accordance with portrait tradition, they do not smile, as "the only expression allowable in great portraiture is the expression of character and moral quality, not anything temporary, fleeting, or accidental." 26 This has been the pose of the rich and the powerful as they have been immortalized through paintings for centuries, and the photographically depicted Victor Tesch, Auguste, Edouard and Emile Metz, Emile Mayrisch, and the likes are clearly recognizable as belonging to this class.

Revue Technique was not the only print outlet to consolidate the image of Luxembourg's steelmakers. The popular weekly magazine $A-Z$ Luxemburger illustrierte Wochenschrift, published from 1933 to 1939, played a significant role in spreading similar ideas to a much broader public. ${ }^{27}$ Indeed, Camille Aschman,

24 Wagner and Aschman, "Fondateurs d'usines, maîtres de forges et grands maîtres de l'industrie sidérurgique luxembourgeoise," $133^{-} 5^{2}$.

25 Ibid., 133.

26 Edward Burne-Jones, cited in Gordon C. Aymar, The Art of Portrait Painting (Philadelphia, PA: Chilton Book Co., 1967), 119 .

$27 \quad A-Z$ was first published on December 24, 1933, and ceased its activities with the German invasion of Luxembourg in 1939. As an illustrated magazine, it wanted to be informative 


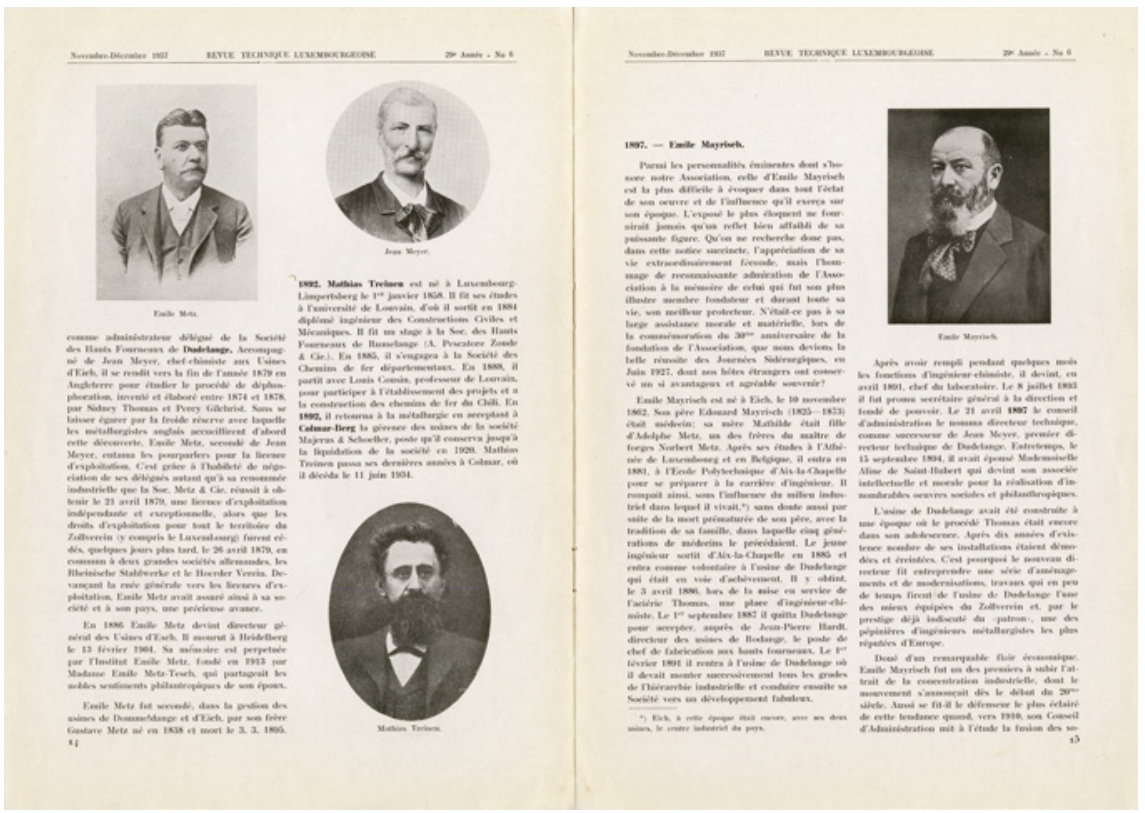

FIGURE 2.1 Spread from a publication on Luxembourg's captains of steel and mining industries. Reprinted from Wagner and Aschmann, "Fondateurs d'usines, maîtres de forges et grands maîtres de l'industrie sidérurgique luxembourgeoise” (1937), $146-47$.

co-author of the historical overview in Revue Technique, had previously published a series of twenty-two articles entitled "Daten aus der luxemburgischen Eisenindustrie" (Data from the Luxembourg steel and iron industry) in $A-Z$ between 1935 and $1936{ }^{28}$ There, Aschman provided not only detailed historical and geographical facts about iron and steel production in Luxembourg, but he also used over 300 images to illustrate his articles. Aschman, himself from a bourgeois family of doctors, entrepreneurs, and industrialists, was particularly

but also entertaining. Taken over in the summer of 1934 by the socialist politician and publisher Hubert Clement, $A-Z$ set out to be an alternative to the dominant Catholic print media targeting families. See also Romain Hilgert, Les journaux au Luxembourg, 1704-2004 (Luxembourg: Service information et presse du gouvernment luxembourgeois, 2004), 188.

28 Published between August 4, 1935, and May 19, 1936, the articles appeared biweekly on a three-page spread. They covered a wide range of subjects, from the earliest exploitation of iron ore in Luxembourg to the history of individual foundries and steel plants, and included even a two-part anthology of writers on the steel industry, where we also find a short biographical notice about Aschman himself. 
interested in the leading cast of the iron industry. While workers are absent from his writings, his texts abound in information about the steel company's leading figures and personalities. Not surprisingly, we find the same portraits in both the illustrated $A-Z$ and the Revue Technique.

Importantly, many of the portraits used for either the article in Revue Technique or the series in $A-Z$ are part of the glass plates collection found at the Institut Emile Metz, where Camille Aschman worked as a chemistry teacher. A conversation that I had with Aschman's great-grandson, Philippe Aschman, in the spring of 2016 further revealed that Camille Aschman also had made glass plates himself, before and during his service at ARBED Dommeldange. The family's private archive proved to be a true treasure trove: It included not only more glass plate portraits from the $A-Z$ articles but also a folder containing the extensive correspondence that Aschman had carried on with the leaders of the steel industry or their families in order to gather the portraits for his writings. He then re-photographed the images and produced negatives from positives to be included in his texts (see fig. 2.2). Through his activities as author and photographer, and because of his contacts to the illustrated press, Camille Aschman thus became instrumental in distributing and disseminating ideas about, and visions of, the Luxembourg steel and iron industry in the 1930s.

In his influential analysis of the origin and spread of nationalism, Benedict Anderson stressed the importance of print media "to create popular vernacular-based" ideas of nationhood in Europe. ${ }^{29}$ Reading a newspaper, he wrote, "created an imagined community among a specific assemblage of fellow-readers." 30 Photographs add a strong visual support in creating a sense of belonging between members of the same cultural group. In Luxembourg, $A-Z$ set out to do exactly that: to unite a national readership around visual

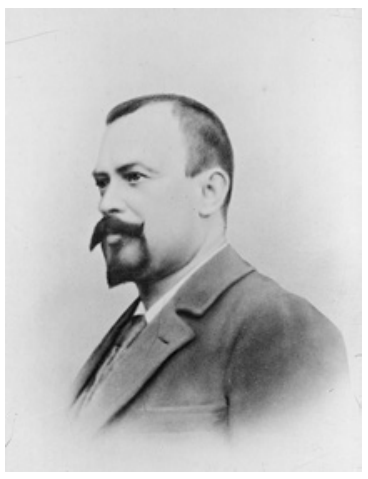

FIGURE 2.2

Nicolas Tockert, director of ARBED Dommeldange, 1897-1900. Digital positive from glass plate negative. (C) institut EMILE METZ. CNA COLlection.

29 Benedict Anderson, Imagined Communities (London: Verso, 1983), 139.

$30 \quad$ Ibid., 62. 
information about the country. Looking back on the challenges of the first two years of publication, the magazine's editor, M. W., in January 1936 stated:

Our country is an extended family, complete with friendships and circles of acquaintances. Even if one lives up north in Uelflingen and the other in Esch, they are almost neighbors. Connections run from almost everyone, across all paths and hamlets of our country; sometimes one forgets, but suddenly there is an image in $A-Z$, and one remembers. The family rummages through its past, and it is obvious that the photos show characteristics of one's own family.

What I want to say is that our illustrated magazine is a precious thing for maintaining among our people the feeling of immediate belonging. It is a good thing to preserve this feeling beyond political conflicts and ideology.

Not to mention the fact that $A-Z$ faithfully disseminates, through images, the festive celebrations, customs and traditions, sports and games throughout the entire country, thus representing an important means of information in this field as well. ${ }^{31}$

As a teacher, Aschman wanted to educate a broader public about the history of the Luxembourg steel industry. Therefore, he provided detailed data and richly illustrated his texts with numerous images. Aschman's solid research gave his texts the necessary weight, while their positive tone conveyed a sense of pride that the author shared with his readers, thus creating a sense of national belonging around the subject of the steel industry. In this imagined community of Luxembourg, the captains of the steel industry, represented authoritatively through photographs, stand out as leading figures. The nation-wide circulation of their portraits clearly contributed to their public prominence. Moreover, the portraits' repeated use helped forge a collective understanding of what it meant to be an industrialist in Luxembourg in the early twentieth century. Eventually, the industrialists' public images and official functions became more important than their private personalities. Individuals such as Emile Metz or Emile Mayrisch were transformed into types through their photographic representation. As national icons they became an integral part of the cultural and industrial memory of the country.

Not surprisingly, representations of men dominate in the glass plate collection from the Institut Emile Metz, and there are almost no women's portraits

$31 \quad$ M. W., "A-Z tritt in ihr 3. Lebensjahr," A-Z Luxemburger illustrierte Wochenschrift, January $5,1936,3$. 


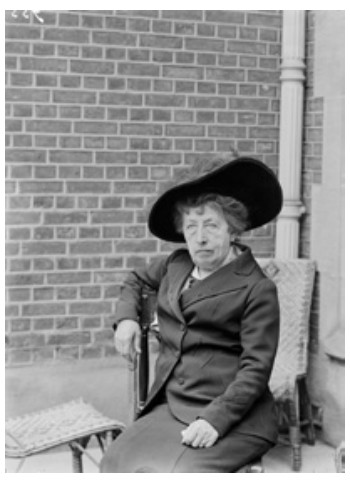

FIGURE 2.3

Edmée Metz-Tesch, ca. 1915. Digital positive from glass plate negative.

(C) INSTitut EMile METZ. CNA COLlection.

to be found until the 1930s-with the exception of Edmée Metz-Tesch who was, after all, the founder of the institute. Indeed, the glass plate collection includes two portraits of Metz-Tesch. The first, in the numerical order of entry at the CNA archive, shows her around 1915 in an informal setting, sitting on an outside terrace or porch (see fig. 2.3). She was around seventy years old at the time, and though her face is marked by age, her light, piercing eyes are resolutely facing the camera. Her hat and clothes match the descriptions of elegance and expensive taste cited earlier. The self-confidence emanating from the portrait seems to confirm that this is a woman who would read the Memoirs of Casanova or the writings of Anatole France and establish a vocational training school with a progressive reformist outlook. Interestingly, not much has been written about Edmée Metz-Tesch. ${ }^{32}$ She is, however, the only woman mentioned by Camille Aschman in an $A-Z$ article about the foundry and steel plant of Dommeldange. Aschman also included a photograph of her, but it is an earlier engraving of Edmée Metz-Tesch, showing her as the young woman that Jules Mersch described in his National Biography (fig. 2.4).

A photographic reproduction of the original engraving by Camille Aschman also figures in the collection from the Institut Emile Metz. Was Aschman's choice motivated by an attempt to render a flattering image of the institute's benefactress or was it rather in keeping with the dominant male view of gendered roles in the steel dynasties? It is difficult to know. While the portrait of the resolute, independent widow leaves a lasting impression, it is her younger, flawless self that would be remembered in the popular imagination.

32 Edmée Metz-Tesch has been largely overshadowed by another important female figure, Aline Mayrisch de Saint-Hubert, and her political and cultural initiatives, such as the Colpach Circle. For a detailed discussion of the role of Aline Mayrisch, see Germaine Goetzinger, "Aline Mayrisch: féministe engagée, philanthrope éclairée, femme de lettres éminente," Mémoires de l'Académie nationale de Metz 194 (2013): 95-107. See also Klaus Dittrich, "Buddhism, Business, and Red-Cross Diplomacy: Aline Mayrisch de SaintHubert's Journeys to East Asia in the Interwar Period," in this volume. 


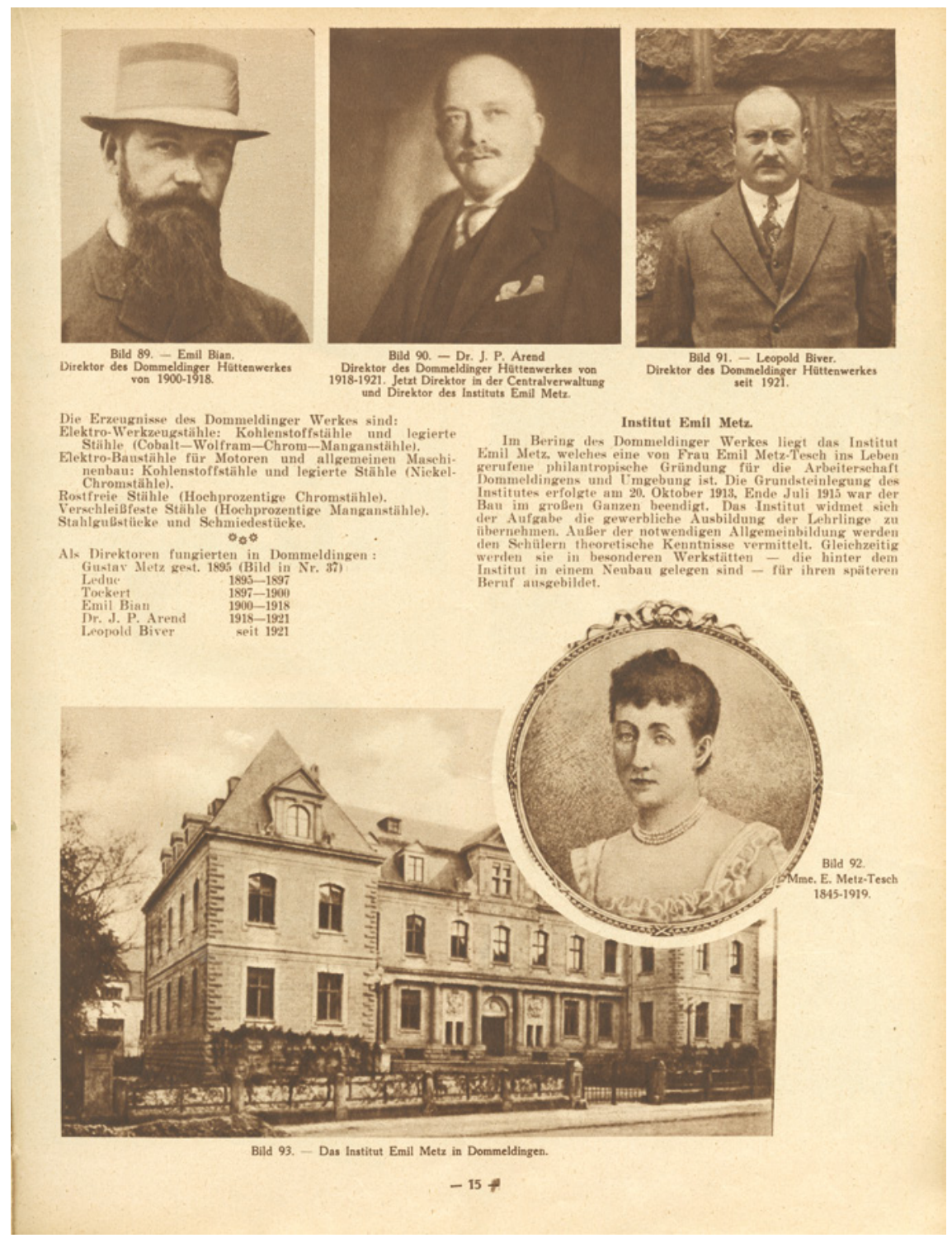

FIGURE 2.4 Page from Aschman, "Daten aus der luxemburgischen Eisenindustrie" (1935), 15.

In the developing era of industrialization, photographs were used extensively in the field of corporate communications, in Luxembourg as elsewhere. The circulation of images about a company and its leaders was an important means to convey stability and trustworthiness to politicians, stockholders, and clients, 
as well as to employees and workers. Interestingly, the glass plate collection from the Institut Emile Metz also contains many portraits of workers associated with factory products of different shapes and sizes, from giant cogwheels to turbines for cruise ships. Work portraits are a significant component of industrial archives, as they have an important double function. Indeed, as American cultural theorist Elspeth Brown pointed out in her analysis of the role of photography in the rationalization of American commercial culture between 1884 and 1929, "photography's indexical qualities made it a potent ideological tool, providing a human face to the otherwise soul-less corporation ... [and] building worker loyalty."33 The work portrait not only represented the human dimension of the industrial environment, it also individualized the worker, conferring upon him visibility and recognition. Therefore, "managers actively worked to create a visual culture of dignified labor as a means of increasing job satisfaction and discouraging unionization." 34

Compared to other international corporations, ARBED had a manageable size, with a maximum of 25,000 workers and employees spread over several plants and firmly rooted in their local communities. The company was less anonymous than many other corporations abroad. The German company Krupp, for instance, had had 75,000 employees as early as 1887, and employment rolls at General Electric in the United States had grown from 6,000 in 1885 to 82,000 in 1920 . There, not surprisingly, "the old paternal relations between management and labor, based on personal ties, could no longer bind the corporation together."35 Luxembourg's ARBED, however, was a different case. Internal communication within the smaller corporation may not have seemed a priority, as may be confirmed by the lack of employee magazines. And the inclusion of workers in images of the company's products may have been partly motivated by practical considerations, such as providing an idea of the scale of the displayed object. ${ }^{36}$

I would argue, however, that the work portraits in the glass plate collection also resonate with concerns for "a visual culture of dignified labor." The image shown in figure 2.5 is a good example. Two gigantic cast iron rings for a blast furnace top are leaning, one slightly overlapping the other, against the brick wall of a production hall. They have been arranged in space for maximum effect, and the image is carefully composed. Vertical and horizontal

33 Brown, The Corporate Eye, 146.

34 Ibid.

35 Nye, Image Worlds, 75 .

36 See Ira Plein's discussion of notions of scale in portraits of workers: Ira Plein, "Machines, Masses, and Metaphors: The Visual Making of Industrial Work(ers) in Interwar Luxembourg" (in this volume). 


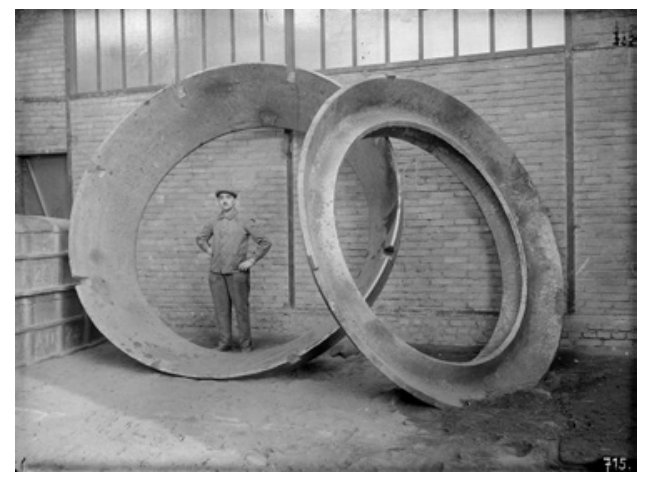

FIGURE 2.5

"Hauts Fourneaux. 1+1 anneau pour gueulard. Tintinger" (Blast furnace. 1+1 ring for blast furnace top. Tintinger). Undated. Digital positive from glass plate negative.

(C) INSTITUT EMILE METZ. CNA COLLECTION.

lines divide the frame, allowing the eye to wander from the elongated frosted window panes at the top, down the finely structured wall, across the dirt floor in the foreground. The circular shapes of the cast iron rings bring a dynamic element to the composition, which is balanced by the inclusion of an upright human figure. A worker wearing work clothes and a beret, hands on his hips, his moustache neatly trimmed, is facing the camera, framed by one of the rings that he most likely helped to produce.

The paper archive related to the glass plate collection allows us to identify the foundry worker by his last name, Tintinger. However, there is no indication about the man behind the camera. The photograph could have been taken by Camille Aschman. After all, he was an employee of ARBED Dommeldange, he was teaching chemistry at the Institut Emile Metz, and he was a photographer who had the necessary skills. While it is impossible, at this later stage, to determine who took this picture, the image reveals nevertheless a complicity between the photographer and the worker; they both take minute care to provide an appropriate setting for the actual subject of the photograph: the industrial product on display. There is, of course, more to the image. The upright position of the worker, his direct gaze, the clear-cut, well-kept face, his entire attitude show his love of, and pride in, a job well done. This is also what links both men, the photographer and the photographed, as their projections and desires meet inside the picture frame: the mutual recognition of their craftsmanship put at the service of ARBED.

Images such as this were used in promotional albums compiled and published by ARBED's sales and public relations office Columeta. ${ }^{37}$ The albums

37 Columeta (Comptoir luxembourgeois de métallurgie) was created on June 19, 1920, as the sales office for ARBED and its sister steel company, Terres Rouges. While photographs were central in forging the image of Luxembourg's steelmakers abroad, film was also used 
showcased extraordinary products and technological achievements, and were intended for customers around the world. Widely circulated, they also contributed to the valorization of the workers involved in the production process. At the same time, these images reinforce our understanding of the subjective body of the worker, his physical appearance and outfits, and the social category or class he belongs to. Compared with the portraits of the steel barons, the workers are clearly distinguished from the industrialists through the environment in which they are portrayed (in this case the production hall), their attire (their work clothes) and often also through their posture-elements that were fixed and circulated through the photographs.

In his discussion of "The Body and the Archive," American photographer and theorist Allan Sekula has stressed that photography, besides serving as an honorific means of representation, has also a repressive function. ${ }^{38}$ Photographs valorize their subjects and at the same time sort them into different categories, confining them to specific spaces and thus repressing the subject. This double system is most visible in portraiture. Indeed, as Sekula notes, "the photographic portraitextends, accelerates, popularizesand degrades atraditional function. This function ... is that of providing for the ceremonial presentation of the bourgeois self." 39 Cheaper, faster, and more readily available than traditional portraiture, photography can be considered a democratic medium, making visual representation possible for all classes of society. ${ }^{40}$ This, in turn, is linked to notions of empowerment for under-represented social groups and classes, or the raising of historical consciousness through photographic representation. These ideas have been discussed in theory and practice, from Jacob Riis's explorations in 1890 of "how the other half lives" in the slums of New York to Christopher Pinney and Nicolas Peterson's "photography's other histories," that is, views of non-western, non-canonical representations. ${ }^{41}$

very effectively as a tool for corporate communication. For a further discussion of this subject, see Charles Barthel, “'COLumeta' ('Vu Feier an Eisen'): Laventure du premier film publicitaire de l'ARBED," Hémecht 2 (1998): 177-206.

38 Allan Sekula, "The Body and the Archive," in The Contest of Meaning: Critical Histories of Photography, ed. Richard Bolton (Cambridge, MA: MIT Press, 1992), 343-88.

39 Ibid., 344, emphasis in the original.

40 For a further discussion of photography's honorific representational functions, see Pierre Bourdieu, Un art moyen: essai sur les usages sociaux de la photographie (Paris: Ed. de Minuit, 1965); Freund, Photographie et société.

41 See Jacob A. Riis, How the Other Half Lives: Studies among the Tenements of New York (New York: Charles Scribner's Sons, 189o; New York: Bartleby.com, 2000); Christopher Pinney and Nicolas Peterson, Photography's Other Histories (Durham, NC: Duke University Press, 2003). 
At the same time, photography has been valued from a very early stage in the history of the medium as a tool for reproducing or translating the threedimensional indexical referent almost perfectly onto a two-dimensional plane. It is commonly believed that photographs accurately depict reality. ${ }^{42}$ In his text, Sekula more specifically refers to medical and anatomical illustrations, where photography "came to establish and delimit the terrain of the other, to define both the generalized look - the typology—and the contingent instance of deviance or social pathology."43 Expanding on Sekula's idea, one could say that photographs have been used scientifically to visualize the norm and its deviances, and thus to create visual categories. By analogy, I want to argue that the portraits from the glass plate collection at the Institut Emile Metz also establish classifications of subjects and subjectivities. Therefore, they too have this double function of valorizing and repressing, which becomes most apparent in the portraits of the workers. As valorizing objects of representation, the photographs allow the workers to be visible and to appear in the corporate picture album. The camera enters and makes visible their work space, together with the product of their labor. At the same time, these photographs define the "worker" as a specific type, confining him to a specific social space. Indeed, defining a type implies the creation of categories and boundaries: objects and people are assigned to clearly defined classes or groups. These classifications are part of an ordering mechanism that functions as a regulatory system: every "body" belongs to a space determined by the hierarchy of the corporation.

In the context of the steel industry, photography thus can be understood as part of the "disciplinary power" in the Foucauldian sense - that is, as part of a "whole set of instruments, techniques, procedures, levels of applications, targets" which act upon the subjective body. ${ }^{44}$ As the glass plates reveal, photography had a regulatory function both inside and outside the company ARBED. Internally, it helped maintain a certain order by building loyalty and corporate identity. To the outside world, corporate photographs, such as the images from

42 For a discussion of photography's indexicality and truth value, see, for instance, Roland Barthes' seminal Camera Lucida: Reflections on Photography, trans. Richard Howard (London: Jonathan Cape, 1982); J. J. Long, Andrea Noble, and Edward Welch, eds., Photography: Theoretical Snapshots (London: Routledge, 2009); Richard Bolton, ed., The Contest of Meaning: Critical Histories of Photography (Cambridge, MA: MIT Press, 1992); Sarah Parsons, The Meaning of Photography (Williamstown, MA: Sterling and Francine Clark Art Institute, 2008).

43 Sekula, "The Body and the Archive," 346, emphasis in the original.

44 Michel Foucault, Power/Knowledge: Selected Interviews and Other Writings, 1972-1977, trans. Colin Gordon (New York: Pantheon Books, 1980), 121. 
the Institut Emile Metz, through their repeated uses and circulations, shaped a certain view and understanding of society and its various components, emphasizing the subjective body and perpetuating distinctions of class and hierarchical order.

"To understand the 'photography effect' in the nineteenth century," stated Jonathan Crary, "one must see it as a crucial component of a new cultural economy of value and exchange, not as part of a continuous history of visual representation." ${ }^{5}$ Or, as Elizabeth Edwards put it, "socially required 'realism,' the ontological scream of the medium, is the very basis for its social meaning. It is what people want photographs to do. This position moves the situation out of photographic and into cultural, social and political questions."46 The glass plate negatives found at the Institut Emile Metz sustain the argument to study the social meaning of photographs, to look more closely at their significance as bundled, material objects, deeply rooted in their historical time and geographical space. This is not to minimize the attraction of the image surface or its power to captivate and trigger interest. However, it is only when we question photographs beyond the visual, when we investigate their circulation or discuss them as material objects translating individual or collective projections, wishes, and desires, that they appear as testimonies of a strong, lived history.

\section{Sources and Bibliography}

Anderson, Benedict. Imagined Communities. London: Verso, 1983.

ARBED. CEuvres Sociales. Luxembourg: Victor Bück, 1922.

Arend, Jean-Pierre. "L'Evolution de l'Institut Emile Metz et l'atelier d'apprentissage." In Institut Emile Metz: Programme publié à la clôture de l'année scolaire 1920-1921, 55-64. Luxembourg: Imprimerie Th. Schroell, 1921.

Aschman, Camille. "Daten aus der luxemburgischen Eisenindustrie." A-Z, October 13, 1935 .

Aymar, Gordon C. The Art of Portrait Painting. Philadelphia: Chilton Book Co., 1967.

Barthel, Charles. "'COLUMETA' ('Vu Feier an Eisen'): Laventure du premier film publicitaire de l'ARBED." Hémecht 2 (1998): 177-206.

Barthes, Roland. Camera Lucida: Reflections on Photography. Translated by Richard Howard. London: Jonathan Cape, 1982.

45 Crary, Techniques of the Observer, 13.

46 Elizabeth Edwards, "Photographs as Strong History?," in Photo Archives and the Idea of Nation, ed. Costanza Caraffa and Tiziana Serena (Berlin: De Gruyter, 2015), 324. 
Bolton, Richard, ed. The Contest of Meaning: Critical Histories of Photography. Cambridge, MA: MIT Press, 1992.

Bourdieu, Pierre. Un art moyen: essai sur les usages sociaux de la photographie. Paris: Ed. de Minuit, 1965.

Brown, Elspeth H. The Corporate Eye: Photography and the Rationalization of American Commercial Culture, 1884-1929. Baltimore, MD: Johns Hopkins University Press, 2008.

Crary, Jonathan. Techniques of the Observer: On Vision and Modernity in the Nineteenth Century. Cambridge, MA: MIT Press, 2005.

Edwards, Elizabeth. "Photographs and History: Emotion and Materiality." In Museum Materialities: Objects, Engagements, Interpretations, edited by Sandra H. Dudley. London: Routledge, 2010. Kindle edition.

Edwards, Elizabeth. "Photographs as Strong History?" In Photo Archives and the Idea of Nation, edited by Costanza Caraffa and Tiziana Serena, 321-29. Berlin: De Gruyter, 2015 .

Edwards, Elizabeth. "Photography and the Material Performance of the Past." History and Theory 48, no. 4 (December 2009): 130-50.

Edwards, Elizabeth. “Thinking Photography Beyond the Visual?” In Long, Noble, and Welch, Photography, 31-48.

Foucault, Michel. Discipline and Punish: The Birth of the Prison. Translated by Alan Sheridan. London: Allen Lane, 1977.

Foucault, Michel. Power/Knowledge: Selected Interviews and Other Writings, 1972-1977. Translated by Colin Gordon. New York: Pantheon Books, 1980.

Freund, Gisèle. Photographie et société. Paris: Éditions du Seuil, 1974.

Goetzinger, Germaine. "Aline Mayrisch: féministe engagée, philanthrope éclairée, femme de lettres éminente." Mémoires de l'Académie nationale de Metz 194 (2013): 95-107.

Grütter, Heinrich Theodor, ed. 200 Jahre Krupp: Ein Mythos wird besichtigt. Katalog zur Ausstellung im Ruhr Museum vom 31. März bis 4. November 2012. Essen: Klartext, 2012.

Herman, Frederik. "Forging Harmony in the Social Organism: Industry and the Power of Psychometric Techniques." History of Education 43, no. 5 (2014): 592-614.

Herman, Frederik, Karin Priem, and Geert Thyssen. "Körper_Maschinen? Die Verschmelzung von Mensch und Technik in Pädagogik, Industrie und Wissenschaft." Jahrbuch für Historische Bildungsforschung 20 (2014): 47-75.

Hilgert, Romain. Les journaux au Luxembourg, 1704-2004. Luxembourg: Service information et presse du gouvernment luxembourgeois, 2004.

Ingold, Tim. "Bindings against Boundaries: Entanglements of Life in an Open World." Environment and Planning A 40, no. 8 (2008): 1796-1810.

Ingold, Tim. Lines: A Brief History. London: Routledge, 2007. 
Institut Emile Metz: Programme publié à la clôture de l'année 1917-1918. Luxembourg: Imprimerie Universelle Linden et Hansen, 1918.

Krupp: Fotografien aus zwei Jahrhunderten. Berlin: Deutscher Kunstverlag, 2011.

Lamesch, Jean. "Histoire de la Fondation Veuve Emile Metz-Tesch." In IEM-LTPEM: 100 Joer 1914-2014, edited by Alphonse Bressanutti, Fernand Champagne, Laurent Kemp, Siggy Kirsch, Pierre Legille, and René Tissier, 69-105. Luxembourg: LTPEM, 2015 .

Latour, Bruno. Science in Action: How to Follow Scientists and Engineers through Society. Milton Keynes: Open University Press, 1987.

Linster, Lise. "Das Institut Emile Metz-eine Stufe zum sozialen Aufstieg." Koplescht, fréier an hott 10 (October 2013): 56-62.

Long, J. J., Andrea Noble, and Edward Welch, eds. Photography: Theoretical Snapshots. London: Routledge, 2009.

Mersch, Jules. "Les Metz, la Dynastie du Fer." In Biographie nationale du pays de Luxembourg, vol. 6. fascicule 12, 383. Luxembourg: Bourg Bourger, 1963.

Nye, David E. Image Worlds: Corporate Identities at General Electric, 1890-1930. Cambridge, MA: MIT Press, 1985 .

O’Mally, Michael. “'Subjectivity'—What Is It?” The Aporetic. http://theaporetic.com/? page_id=2184.

Parsons, Sarah. The Meaning of Photography. Williamstown, MA: Sterling and Francine Clark Art Institute, 2008.

Pinney, Christopher, and Nicolas Peterson. Photography's Other Histories. Durham, NC: Duke University Press, 2003.

Poos, Françoise. "The Making of a National Audio-Visual Archive: The CNA and the Hidden Images Exhibition." PhD diss., De Montfort University, 2016.

Riis, Jacob A. How the Other Half Lives: Studies Among the Tenements of New York. New York: Charles Scribner's Sons, 1890; New York: Bartleby.com, 2000.

Rose, Gillian. Visual Methodologies: An Introduction to the Interpretation of Visual Materials. 2nd ed. London: SAGE Publications, 2007.

Sekula, Allan. "The Body and the Archive." In Bolton, The Contest of Meaning, 343-88.

Tenfelde, Klaus, ed. Bilder von Krupp: Fotografie und Geschichte im Industriezeitalter. Munich: C. H. Beck, 1994.

W., M. "A-Z tritt in ihr 3. Lebensjahr." A-Z Luxemburger illustrierte Wochenschrift, January $5,1936,3$.

Wagner, Jos[eph], and Camille Aschman. "Fondateurs d'usines, maîtres de forges et grands maîtres de l'industrie sidérurgique luxembourgeoise." Revue Technique Luxembourgeoise 29, no. 6 (November-December 1937): 133-52. 